\title{
Models of Christian Feasts as a Plot-Constructing Topos of V. Rasputin's Prose
}

\author{
Vasilina A. Stepanova* \\ Siberian Federal University \\ 79 Svobodny, Krasnoyarsk, 660041, Russia
}

Received 14.02.2015, received in revised form 20.04.2015, accepted 23.05.2015

This article deals with the models of Christian feasts as an important plot-constructing topos of Rasputin's prose. The method of the analysis is hermeneutic. The Christian orientation of the writer's prose manifests itself in his oeuvre in signs, symbols and logical system of the plot, which is associated with the Orthodox picture of the world. The motif of death, leading to the creation of the writer, is developed in accordance with the logic of the Christian feasts: Candlemas, Assumption, Transfiguration, Resurrection and Ascension. The models are significantly transformed; Christianity is presented at the level of intentions in the dialogue with the pagan, indicating that the writer's worldview is dual. It is important to understand the convention of festive models incarnation since the text is not composed upon the canon. However, the idea of death, formed in Orthodox culture through the feasts as well (one of the first actions aimed at the destruction of paganism was replacing pagan feast by the Christian ones), is reflected in the V. Rasputin's prose. Summing up, we could say that the choice of festive models and rites, associated with it, is a sign of new emphases in the writer's worldview.

Keywords: Rasputin, Candlemas, Assumption, Transfiguration, Resurrection, Ascension, dualism.

The research is carried out within the frame of project No 14-14-24003 supported by the grant of the Russian Foundation for Humanities.

DOI: 10.17516/1997-1370-2015-8-7-1451-1458

Research area: philology.

\section{Introduction}

Modern literary criticism has traditionally studied V. Rasputin's works in the context of Christian worldview (I. Kazantseva, O. Barysheva, N. Smirnova, etc.). The writer also insists on such reading of his texts. His Christian orientation manifests itself both in journalism and artwork: the heroes in the stories are allusively associated with the saints' images ("Sofia-like" female characters, "St. George", "St.
Nicholas" complexes); the plot usually develops in the logic of the Orthodox view on the world; Christian symbols are explicit. Chronotopos is focused on the church calendar. Thus, key events take place on the eve of major feasts. Christmas, Epiphany and Holy Protection are very often mentioned. However, one cannot deny the fact that V. Rasputin's works display not only their Christian foundation but also the elements of paganism (brownies, mermaids, the Owner of

(C) Siberian Federal University. All rights reserved

* Corresponding author E-mail address: burivouh@mail.ru 
the island) and shamanism ("Krai vozle samogo neba" ("The Land Next to the Very Sky"), 1966), thus forming a belief in two different religions which is peculiar to the Russian culture in general. Christianity is divided into Orthodoxy (which is impossible to isolate in its pure form) and Old Belief (which is characteristic to the writer's village prose). Rasputin's later work gets a trace of speculative metaphysics (Rybal'chenko, 2007, 6-26) as a variant of an intellectual hero's transformed religion. The writer's worldview is a complex synthesis of the attitudes mentioned above. Yet, these are Christian or Russian agrarian feasts that are most commonly chosen as time reference points.

\section{Problem statement}

This article is mainly focused not on the chronotopos proper but on constructing the plots on the models of Christian feasts, reflecting the most important milestones in the Blessed Virgin's and Christ's being (these are divided into domonical and deiparous) (Zadorozhnaia, 1991, 8). The holidays symbolically familiarize people with biblical events. Thus, composing the plot on their model duplicates a sacred act proper.

\section{Models of Candlemas and Assumption as feasts of preparation to death}

Perception of death as a feast roots from the faith in the Resurrection of Christ and immortality of the soul. It is a common thing throughout Rasputin's mature works: the old woman Anna sees a rainbow at the moment of enlightenment before death; dying Nastyona hears the bells "calling $<\ldots>$ someone to holiday" (Rasputin, 2007b, 254); in "Farewell to Matyora" (1976) decorating the houses (izbas) before the flood is accompanied with festive rituals making lime by old Darya, whitewashing the chamber. It is important that this perception of death is peculiar for the righteous persons only.
In later stories this parallel is conceptualized in a new way: Aksinya Egorovna ("V tu zhe zemliu" ("Into the Same Earth), 1995) dies when Pashuta, her daughter, is on "a special customer service". The event is not important. It is celebrated by some "unimportant organization" that is regarded as a sign of a collective, formal nature of the event. Chronologically it serves the time reference point of the ordinance of death. Aksinya Egorovna dies alone, in her sleep (Stepanova, 2014, 277).

In the writer's poetics perception of death as a feast precedes a symbolic Ascension. As for Resurrection, the path of repentance and redemption is necessary for it. It is worth while noting that Resurrection naturally precedes Ascension. Yet, the righteous persons, depicted by Rasputin as those who already attained holiness, skip the act of making atonement and are immediately taken into another world.

Preparation for death is most fully embodied in the models of Candlemas and Assumption feasts depicted in the story "The Last Term" (1970). Waiting for the transition is connected with looking forward to meeting with the daughter. The motif of the need to meet with a child to get one's quietus duplicates the model of Candlemas. It is the expectation that is associated with the feeling of the end, the last term which justifies the title of the story: "Tan'chora can come only today, this is the last term for her to be released" (Rasputin, 2007b, 146). The lexeme "release" is an allusion to Simeon's prayer: "Now Lord, You are releasing Your bond-servant to depart in peace" (Luke, 2:29). The aged nun Anna was a witness of the elder Simeon's meeting with the Messiah. The failure to meet with Tan'chora is a "sin" for the mother which she should be purged of before the Court of God. Her words "You've let me die without meeting with Tan'chora" (Rasputin, 2007b, 165) involuntarily evoke associations with death without Sacrament. 
Assumption is treated as "a short sleep before birth into a new life" (Assumption of the Blessed Virgin, 2003). In the story the perception of death is directly connected with Anna's dream. Anna imagines this transition the following way: "She will fall asleep not in its ordinary way, unconsciously but memorably and with warmth as if descending the steps somewhere down" (Rasputin, 2007b, 176).

The scene, unveiling to Anna, correlates with several discourses: the Slavs were washing the dead on the straw; the motifs of a miraculous staircase, chimes of the bells refer to the iconographic tradition to portray the Virgin and are highlighted by the legend of Kitezh: light and chimes of the bells are integral parts of a righteous person's transition into another world. The heroine talks to the death, literally drawing a contractual agreement with it, which also correlates to archaic practices. Before passing away Anna wants to fall asleep in order not to "scare the death with her eyes open" (Rasputin, 2007b, 172).

Anna thinks that after the transition "the eyes will fall off and get lost in the straw. The stairs will also disappear - until next time. The earth will become smooth and the morning will come. Live morning" (Rasputin, 2007b, 177). In fact, death is embedded in a life cycle. It is just one of the turns of life (after death there comes a reviving morning).

Coming back to one's family is given a special emphasis in the course of transition:

\section{And from the Mother Church \\ Into the Mother Earth \\ To your family (Rasputin, 2007b, 204).}

Apart from the fact that the rite of crying is pagan, the transition from the church to the earth, to the family emphasizes a greater importance of ties with the ancestors rather than with Orthodox religion - the Church is merely a transitional space.

Dwelling upon the specifics of foregrounding the model of Assumption as a plot-constructing topos of the text, it should be clarified that allusions do not imply direct identification. An important detail here is that after Christ's crucifixion the Virgin remained in the care of St. John the Theologian. In the story Anna lives at her younger (younger than Tan'chora!) son Mikhail who is portrayed with a focus on the patriarchal order. Of all Anna's children only he stays near the dying in the sacred space of the chamber, performing his destined functions. Mikhail is inscribed in the traditional paradigm - he has taken his fate. This results in the hero's nondenying of the mystery of death, passing away.

Madonna was warned by the Archangel Gabriel about her coming death. In V. Rasputin's works this narrative construct can be traced: only the righteous get the right to prepare for death, death is shown as entrance to the metaphysical. The old woman Anna makes arrangements with death. This serves a clear evidence of synthesis of Christian and pagan philosophical systems. Similar agreement is concluded by aunt Natalia, directly named the holy, in the story "Money for Maria".

On the day of Dormition of the Theotocos the apostles gathered to bid their farewell to her and only Thomas was absent. It is clear that it is impossible to compare the old woman's children (alienated from the family, bereft of their destiny!) with the apostles. However, the foregrounding of the structural model is obvious: all the children come to say goodbye to their mother except for one - Tan'chora. The Assumption is described as follows: "The Virgin was lying on the death-bed, besprent with flowers, and waiting for Her Son. Suddenly infinite light began to shine, darkening the lamps; the chamber's roof opened and Christ himself came down" (Skaballanovich, 1916, 2). 
The opened roof, radiant light, the old woman's firm belief that her death will be "easy" as "there is no need for them to torture each other in the end" are the constructs that prove Assumption to be the plot-constructing model of "The Last Term".

In the writer's later work the model is extremely minimized. However, the description of the righteous' death will be also associated with the Virgin's code both stylistically and symbolically. The connection of death with the space of sleep is one of the toposes: Nastyona is "exhausted to sleep"; having awaked from their sleep in Bogodul's "henhouse", Matyora old women felt dead; in "Pominnyi den"” ("Funeral day") Senya falls asleep on the place of a flooded cemetery. Pashuta ("V tu zhe samuiu zemliu" ("Into the Same Earth"),1995) puts "a pillow under her dead mother's head as if for a sleep" (Rasputin, 2007b, p. 276). The old woman's image is given a focus on iconographic canons that reinforces a symbolic link with the Virgin (Kovtun, 2015, pp. 58-74).

In the final story "Ivan's Daughter, Ivan's Mother" (2003) a feast will precede a symbolic death. Before setting off to revenge Tamara decides to "make dinner" (Rasputin, 2007b, p. 217). A festive meal is sacral in itself but here it is rather a funeral feast of life gone and lost forever. A meal is also of a uniting - at least formally - nature, everyone gathers around the table. Tamara's revenge was aimed at the family's protection. She does not believe in justice but judges herself. At the same time she willingly sacrifices herself for the sake of protecting foundations and principles and refuses to obey the rules of the world that changed and plunged into chaos. This sacrifice partly relates her to the image of Christ, but in her case the Judge comes to replace mercy and forgiveness. A shared meal, which is analogous to the Lord's Supper, precedes the way of the Cross. It also substantially rethinks it over. Death as a feast is transformed into an attempt to unite formally, but its impossibility signifies the necessity of the heroine's way of the cross.

It is definitely impossible to compare the image of Tamara Ivanovna with the image of Christ: the initial message of revenge is unacceptable to the Orthodox tradition. However, in the context of the new world there is no hope for salvation from the outside. Thus, not only rituals, customs, and holidays but also the characters' worldview foundations and principles are transformed. The image of Tamara Ivanovna is often associated with the image of the Virgin. This is proved at the level of symbols. Yet, Madonna's protective mission cannot be realized through murder. As a matter of fact, the court held is a restoration of Talion's law: "eye for eye,

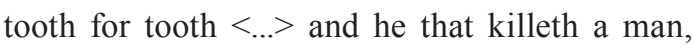
he shall be put to death" (Leviticus 24:19-21). In fact, in V. Rasputin's later works there is a move from New Testament truths to Old Testament one, Talion's law is foregrounded (Kovtun, 2010, pp. 80-93). That is why Exodus / Resurrection are impossible in the texts of the 90s - 2000s: the absence of Christ deprives of the prospects of Resurrection. Christianity is foregrounded at the level of intentions in the dialogue with pagan, natural models and codes that proves the dualism of the writer's works.

\section{The Model of Ascension}

The motif of preparation for death is logically followed by the model of Ascension. In the story the heroine is surrounded by Sophian elements: air, sky, sunlight. Anna's fate is actually inscribed in the hagiographic canon even when she is alive. Anna's death is both a new birth and a transition into a sacral space. Since the old woman is endued with the traits of the saints in her lifetime, it is needless say about Exodus and Resurrection. The old woman's 
death rather duplicates the model of Ascension, merging of a materialized image of Sofia with her heavenly nature.

The Ascension model will also function in the story "Farewell to Matyora". In folk tradition Ascension and its eve "were considered feasts of the dead. $<\ldots>$ At this time the souls of the dead can visit their near relations, and any deceased and even a sinner or he who has died unnatural death freely get to Heaven" (Osnovy..., 2000). According to V. Rasputin, silent, unnoticeable transition into the otherness means readiness to death. Such a transition duplicates the model of Ascension (the story "The Last Term"). The story "Farewell to Matyora" foregrounds the same model. It seems interesting that the island is also at its last term: "But this summer is the last: it will flood in the autumn" (Rasputin, 2007b, 11). Thus, preparedness to death openly reigns on the island. This evidently portends a catastrophe as all the elements become hostile (water - flooding, fire - madness). The island is both a paradise and an island of the dead.

The denouement of the narrative is ambiguous. The alleged ascension is duplicated with the description of the flooding. The old women feel dead. They describe the transition as follows: "I flew in the darkness and didn't look at the light" (Rasputin, 2007b, 233). Traditionally the fog is a symbol of the border between the real and the unreal; in Christianity it precedes Revelation. In fact, the writer finishes the text with a moment of transition: the island ascends, moves to another space. The story model definitely duplicates the folk perception of the feast, but transforming it. In V. Rasputin's mature works the construct will be changed even more essentially: in the story "Izba" ("The Village House") the death that continues the present will be presented as the entrance to the metaphysical, a travel to another, but existing within the narrative, space (the same technique will be used in the story "Videnie" ("Vision").

Parallel of Ascension and drowning is repeated in the writer's prose a number of times. Thus, before her death Nastya ("Live and Remember", 1974) sees in the water "the scintillation, as if from a pretty creepy tale, - the sky flew and trembled in it" (Rasputin, 2007b, 253). The possibility of getting to the sky through the water is the completion of her way of the cross, some granted forgiveness.

The Ascension model implies a hero's static state. It is either achieved through ordeals (thus, the prior motifs of the way of the Cross and Resurrection are necessary) or naturally results from a hero's life and destiny (the righteous old women, the God's fools do not change in the texts).

\section{The models of Transfiguration and Resurrection}

The image of transfiguration as an invariant of the plot is distinguished in V. Ivanova's works. She defines it as "a verbal link of images and motifs with a conventional nomination 'callmountain-meeting-light"” (Ivanova, 2014, 268). The invariant reveals itself in many texts: "The Last Term", "Natasha" (1981), "You Live and Love" (1981), "Na Afone" ("On the Mount Athos") (2004). However, it is worth remembering that the meaning of Transfiguration is not in renewal and change but in "understanding of voluntary suffering" (kontakion of the feast), signifying the beginning of the way of the Cross. Transfiguration is impossible without subsequent Resurrection.

The way of the Cross is most vividly depicted in the story "Live and Remember". Its heroine's name is Anastasia that means "brought back to life, resurrected". In iconography Sofia is portrayed with a purple face, wings and hands being symbols of sunrise and resurrection. Sofia's colour array reveals itself before Nastyona's 
telling her husband about her pregnancy. Thus, association with Sofia is a prevenient justification of sin. It determines the possibility of Exodus.

Nastyona's pregnancy is named as "the way of the Cross" the end of which predictably leads to crucifixion. The death of the heroine, sharing the responsibilities with her husband and taking his sin, is predestined. At the moment of death the she sees the light on the bottom of the river (an archetypal image). The glow testifies of a mysterious fire associated with Transfiguration in Christianity. Another important factor is that the heroine is "exhausted to sleep", which is a sign of the transition state. It is noteworthy that regarding her pregnancy as the way of the cross, Nastyona thinks of the ascension: "She will not be probably left without mercy, and when in need she will be helped and may well be taken to heaven for her sufferings" (Rasputin, 2007b, 114).

The heroine's suicide is the climax of the story, its threshold situation making it possible to dwell upon the predominance of one or another discourse on the basis of the logic of the story. In Orthodoxy a suicide is a grave sin, "a blasphemy against the Holy spirit of God" (see N. Berdyaev "Of Suicide"), and it consequently prevents from transfiguration. In paganism they had a practice of "mutual death" when they sacrificed themselves to the deceased spouse. According to this position, Andrey dies not physically but only mentally and spiritually. Thus, the replacement of a victim takes place. Rasputin tells about this himself: it was Andrey who had to die but not Nastyona. Suicide most logically fits in some old believers' self-immolations - the death through cleaning elements as a transition to heaven (it is known that Atamanovka is a real toponym, an old believer settlement; in other stories Maxim Vologzhin, one of the characters, will be directly associated with the kerzhaks (the old believers)). It is also important that Nastyona will be mourned and buried, and thus, her sin is forgiven. In fact, the plot testifies of the destruction of the flesh for the salvation of the spirit (the natural law of survival does not work here).

Nastyona's way of the cross ends with the Ascension as a natural result of the Resurrection, Transfiguration functionally precedes these models. However, the invariant of Resurrection is substantially transformed in the story "Pozhar" ("The Fire") (1985). When Ivan Petrovich, a patriarchal character, goes to the field in the final part of the story, it undoubtedly means his pathway to his death. A bare, snow-covered field serves a sign of absolute emptiness, death. At first glance, a white field Egorov crosses is also a sign of death and a final end of cosmogony. In iconography the white color is the deepest and most mysterious. It is "the image of Tabor Light eternal divine energies. $<\ldots>$ this light is beyond space and time" (Isaeva, 2011, 102). Through the symbolism of color the field becomes a space of eonotopos.

The narrator speaks of the coming of spring and notes that "no land is rootless" (Rasputin, 2007a, 81). He considers the unity with nature to be a true path. This introduces a new variant of exit from the profane space: expiational sacrifice has been performed, the old world has been mourned, and the hero leaves for another space giving hope for the revival of nature (Kovtun, 2013, 77-87). The model of Resurrection is interpreted through the natural space. Combining discourses, it is foregrounded together with the symbols of Transfiguration and Ascension that is determined by the meaning and chronology of the feasts.

\section{Conclusion}

The models of Christian feasts foregrounded in the text are in some way or another connected with death and overcoming of it which is the basis of Christianity. The conditionality of festive patterns evocation is important to understand 
since the text is not composed according to their canon. However, the concept of death, formed by the Orthodox culture including the feasts (these were one of the first actions aimed at the destruction of paganism, its replacement with the Christian feasts), is reflected in the writer's prose. Other than the models discussed in the article, the significant feasts in V. Rasputin's texts are those of Holy Protection (in the writer's later works old women deaths come in this period, and the snow covering the grave is a symbol of forgiveness and transition) and the Feast of the Holy Spirit or Trinity (on this day the gifts are brought not to the church but to the kingly larch, that specifies the change of accents in prose).

\section{References}

1. Augustine Aurelius (1879-1908) O soglasii evangelistov [On agreement of the evangelists]. Available at: http://dugward.ru/library/avgustin/avgustin_o_soglasii_evangelistov.html

2. Bezrukova V.S. Osnovy dukhovnoi kul'tury (entsiklopedicheskii slovar' pedagoga) [Fundamentals of spiritual culture (encyclopedic dictionary of the teacher)]. Ekaterinburg, 2000. 937 p.

3. Isaeva M.V. (2011). Simvolika tsveta v ikone [Colour symbols in the icon]. Voprosy kul'turo;ogii, (5), 101-104.

4. Ivanova V.Ia. Obraz preobrazheniia kak obrazno-siuzhetnyi invariant v proze V.G. Rasputina [The image of transfiguration as figurative-and-plot invariant in V.G. Rasputin's prose]. Tvorchestvo Valentina Rasputina: otvety i voprosy (Valentin Rasputin's works: questions and answers). Irkutsk: Irkutsk State University, 2004. Pp. 268-276.

5. Kovtun N.V. (2010). Staruka, angel, bogatyrka: genekraticheskii mif sovremennoi traditsionalistskoi prozy [An old woman, angel, heroine: a genecratic myth of modern traditionalist prose]. Literaturnaia ucheba, (4), 80-93.

6. Kovtun N.V. (2013). Patriarkhal'nyi mif $v$ traditsionalistskoi proze rubezha XX-XXI vv. [Patriarchal myth in traditionalist prose of the turn of the XX - XXI centuries]. Siberian philological journal, (1), 77-87.

7. Kovtun N.V. (2015). "Zhenskii vopros" v tvorchestve V. Rasputina ["Women's question" in V. Rasputin's works]. Philological Sciences (Scientific Essays of Higher Education), (1), 58-74.

8. Florenskii P.A. Ikonostas [Iconostasis]. Moscow: ASTS, 2005. 204 p.

9. Rasputin V.G. Pozhar [The Fire]. V poiskakh berega [In search of the shore]. Irkutsk, Publisher Sapronov, 2007a. $528 \mathrm{p}$

10. Rasputin V.G. Sobranie sochinenii: v 4 tomakh [Collected works: in 4 volumes]. Tom 1. Ver zhivi - vek liubi: povesti, rasskazy (Vol. 1: You Live and Love: stories). Tom 2. Poslednii srok: povest', rasskazy (Vol. 2. The Last Term: stories). Tom 3. Zhivi i pomni: povest', rasskazy (Vol. 3. Live and Remember: stories). Irkutsk: Publisher Sapronov, 2007b.

11. Rybal'chenko T.L. Intuitsiia metafizicheskogo $\mathrm{v}$ proze V. Rasputina [Intuition for the metaphysical in V. Rasputin's prose]. Tri veka russkoi literatury: Mezhdunar. Nauch. Konf., posviashch. 70-letiiu V. rasputina: materialy (Three centuries of the Russian literature: Proceedings of the international scientific conference devoted to the 70th anniversary of V. Rasputin). Moscow; Irkutsk. 2007. Pp. 6-26.

12. Skaballanovich M. Khristianskie prazdniki. Kniga 6. Uspenie Presviatoi Bogoroditsy [Christian feasts. Book 6. Dormition of the Theotokos]. Kiev, 1916.116 p. 
13. Stepanova V.A. Obriad i ritual v pozdnem tvorchestve V. Rasputina (na material rasskaza "V tu zhe zemliu") [Ceremony and ritual in V. Rasputin's later works (based on the story "Into the Same Earth”). Tvorchestvo Valentina Rasputina: otvety i voprosy (Valentin Rasputin's works: questions and answers). Irkutsk: Irkutsk State University, 2004. Pp. 276-287.

14. Uspenie Presviatoi Bogoroditsy [Assumption of the Blessed Virgin]. Available at: http:// sinodipc.ru/page/461/

15. Zadorozhnaya M.Ia. Narodnye i pravoslavno-khristianskie prazdniki [Folk and Orthodox Christian feasts]. Moscow: Znanie, 1991. 64 p.

\section{Модели христианских праздников \\ как сюжетообразующий конструкт \\ прозы В. Распутина}

В.А. Степанова

Сибирский федеральный университет

Россия, 660041, Красноярск, пр. Свободный, 79

В статье рассматриваются модели христианских праздников как значимьй сюжетообразующий топос прозы В. Распутина. Используется герменевтический метод анализа. Христианочентричность прозы писателя реализуется через знаки, символы, логику развития сюжета, связанную с православной картиной мира. Мотив смерти, ведущий в проще писателя, развивается в соответствии с логикой христианских праздников: Сретение, Успение, Преображение, Воскресение, Вознесение. Модели существенно трансформируются, христианство реализуется на уровне намерений в диалоге с языческим, что свидетельствует о дуализме писательского мировоззрения. Важно понимать условность воплощения моделей праздников, поскольку текст построен не по канону. Тем не менее идея смерти, формируемая православной культурой, включая праздники (одно из первых действий, направленных на изживание язычества, было замещение праздников христианскими), осмысляется в прозе В. Распутина. Таким образом, изменение моделей праздников и связанных с ними ритуалов - знак смещения акцентов авторского мировоззрения.

Ключевые слова: Распутин, Сретение, Преображение, Успение, Воскресение, Вознесение, дуализм.

The research is carried out within the frame of project No 14-14-24003 supported by the grant of the Russian Foundation for Humanities.

Научная специальность: 10.00.00 - филологические науки. 